\title{
ISOLASI PIGMEN KAROTENOID PADA KEPITING Metopograpsus sp. BETINA
} (Isolation of carotenoid pigmen in crabs of female Metopograpsus sp)

\section{Franciskus K.I. Manik', Darus Saadah J. Paransa', Desy M.H. Mantiri ${ }^{1}$ Elvy L. Ginting ${ }^{1}$, Veibe Warouw ${ }^{1}$, Rudy Moningkey ${ }^{2}$}

\author{
1Program Studi IImu Kelautan, Fakultas Perikanan dan IImu Kelautan, Universitas Sam Ratulangi, \\ Manado \\ ${ }^{2}$ Jurusan Manajemen Sumber Daya Perairan, Fakultas Perikanan dan IImu Kelautan, Universitas Sam \\ Ratulangi, Manado \\ *Corresponding Author: Darus Saadah J. Paransa. darusparansa@unsrat.ac.id
}

\begin{abstract}
Metopograpsus sp is one of species of crabs usually found in indo-pacifik and lived at mangrove's trunk. The characteristic of this type of crab has type color on the carapace organ that indicate the presence of carotenoid. carotenoid pigments are natural dyes in plants and crustacea. The purpose of this study is to determined type of carotenoid pigments of metopograpsus sp by using TLC Method. The result of this study were identified three type of pigments of metopograpsus sp that are $\beta$-Karoten, Astaxanthin, dan Astacene.
\end{abstract}

Key word : Metopograpsus sp, TLC, Carotenoid pigments.

Metopograpsus $\mathrm{sp}$ adalah kepiting mangrove yang biasanya ditemukan di Indo-Pasifik dan hidup dibatang pohon mangrove. Ciri khas dari kepiting ini memiliki corak berwarna pada karapasnya sehingga diasumsikan kepiting tersebut mengandung pigmen karotenoid. pigmen karatenoid adalah pewarna alami yang terdapat pada tanaman dan hewan krustasea. Tujuan dari penelitian ini untuk mengetahui jenis-jenis pigmen karotenoid pada kepiting Metopograpsus sp dengan menggunakan metode KLT. Hasil penelitian terdapat tiga jenis pigmen karotenoid yang teridentifikasi pada kepiting Metopograpsus sp yaitu : $\beta$-Karoten, Astaxanthin, dan Astacene.

Kata Kunci : Metopograpsus sp, KLT, pigmen karotenoid

\section{Pendahuluan}

Latar Belakang: Kepiting merupakan salah satu organisme laut yang termasuk dalam golongan krustasea (Poore, 2004). Menurut Prianto (2007), ekosistem kepiting terdapat di darat, air tawar dan air laut dengan ukuran kepiting yang beranekaragam. Menurut Poupin and Juncker (2010), kepiting air laut memiliki habitat yang beraneka ragam yaitu daerah hutan dan supratidal, daerah lingkungan air payau, daerah pantai berpasir, daerah pantai berbatu, terumbu karang, serta mangrove. jenis-jenis kepiting tertentu yang biasanya ditemukan di daerah mangrove seperti dari suku Ocypodidae, Sesarmidae, Macropthalmidae, Porcellanidae, Portunidae, Varunidae dan Grapsidae (Pratiwi dan Rahmat, 2015). Salah satu genus dari family Grapsidae adalah genus Metopograpsus.

Metopograpsus $\mathrm{sp}$ merupakan salah satu jenis kepiting yang memiliki corak berwarna pada karapasnya sehingga diasumsikan kepiting tersebut mengandung pigmen karotenoid. Karatenoid adalah pigmen alami yang disintesis oleh tanaman, alga, jamur, kapang dan bakteri. Karotenoid juga ditemukan dalam ikan (salmon, trout, sea beam, kakap merah, dan tuna), kulit, cangkang atau kerangka luar hewan air, seperti moluska (clam, oyster, scallop) dan krustasea (lobster, udang, dan kepiting) mengandung pigmen karotenoid yang diperoleh melalui makanannya (Sari dan Abdiani, 2015). Menurut Britton dkk (1995), Penentuan jenis pigmen dilakukan menggunakan metode pemisahan Kromatografi Lapis Tipis (KLT). Kromatografi Lapis Tipis (KLT) merupakan metode yang sederhana dan cepat dalam pemisahan senyawa pada suatu sampel (Rohman, 2009). Larutan pengembang yang paling baik dalam metode pemisahan KLT adalah pengembang semipolar yaitu PE dan Aseton (Mantiri,1997). 


\section{Metode Penelitian}

Lokasi Pengambilan sampel:

Pengambilan sampel dilakukan di pesisir pantai berbatu daerah mangrove perairan desa Mokupa, Kec. Tombariri Kabupaten Minahasa, Sulawesi Utara.

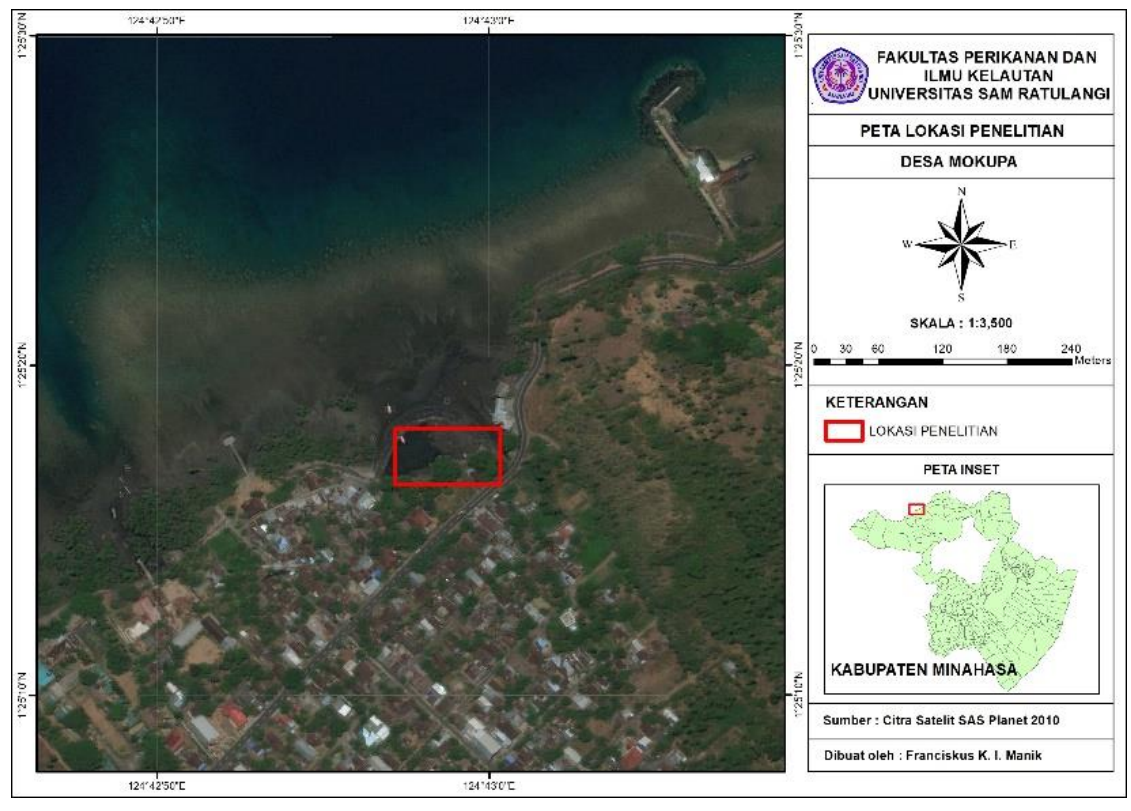

Gambar 1. Peta lokasi pengambilan sampel

Sampel kepiting di tangkap pada malam hari saat air surut dengan menggunakan tangan kosong. Sampel yang telah diambil dimasukkan ke dalam ember. Kemudian diidentifikasi menurut panduan $(\mathrm{H}$. MilneEdwards 1853 dalam yamindago et al. 2013; WORMS, 2019). Sampel yang telah diidentifikasi kemudian dibedah agar diperoleh organ luar karapas dan organ dalam yaitu lapisan epidermis (LE), hepatopangkreas $(H)$, gonad $(G)$ dan hemocyanin (D).

Ekstraksi: Proses ekstraksi mengikuti panduan Britton dkk (1995). Setiap organ yang diperoleh digerus sampai berwarna putih. Khusus pada organ karapas direndam dengan HCL 2N. Masing-masing organ yang sudah digerus ditambahkan larutan aceton dan heksan, kemudian didiamkan sampai terjadi pemisahan. Setelah terjadi pemisahan, lapisan bagian bawah dibuang dan lapisan bagian atas diambil sebagai ekstrak pigmen total. Selanjutkan ekstrak pigmen total dilakukan serapan spektrofotometer UV-Vis dengan panjang gelombang 380-550nm. Hasil serapan spektrofotometer digunakan untuk menentukan nilai konsentrasi dan kandungan dengan menggunakan rumus matematis merujuk pada Briton $d k k$ (1995).

Rumus Menghitung Kandungan Pigmen dan Konsentrasi Pigmen

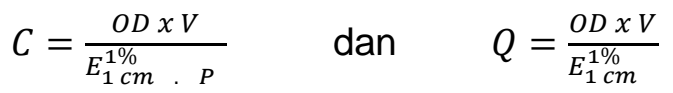

Keterangan:

$$
\begin{aligned}
& \mathrm{Q}=\text { Kandungan Pigmen }(\mu \mathrm{g}) \\
& \text { C }=\text { Konsentrasi Pigmen }(\mu \mathrm{g} / \mathrm{g} \text { berat residu } \\
& \text { kering) } \\
& \text { OD = Kepadatan Optik / Optical density } \\
& \text { (pengukuran dengan spektrometer) } \\
& \mathrm{V}=\text { Volume Pigmen }(\mathrm{ml}) \\
& E_{1 \%}^{1 \%}=\text { "Extinction Coefficiant" Spesifik dari } \\
& E_{1}^{1} \mathrm{~cm} \text { Pigmen Astaxantin }(0,21) \\
& \mathrm{P} \quad=\text { Berat Residu Kering }(\mathrm{g})
\end{aligned}
$$

Pemisahan KLT: Pemisahan pigmen karotenoid dengan menggunakan KLT diawali dengan penyiapan sampel yang telah diekstrak, plat silika gel sebagai fase diam dan larutan pengembang PE : Aseton (80:20) sebagai fase gerak. Setiap fraksi yang diperoleh dilakukan serapan spektrofotometer. 


\section{Hasil dan Pembahasan}

Identifikasi Sampel: Sampel yang diambil dari desa Mokupa, Kec. Tombariri Kabupaten Minahasa, Sulawesi Utara (Teluk Manado) memiliki ciri-ciri yaitu warna hijau kehitaman pada karapas, memiliki kaki jalan dan tidak memiliki kaki renang, capit (dactylus berwana ungu dan finged finger berwarna putih) dengan ukuran kecil, bagian luar kaki jalan berwarna ungu, memiliki duri kuning pada ujung kaki, ruas abdomen lebih melebar pada bagian ujungnya atau menyerupai huruf "U". Berdasarkan panduan $(\mathrm{H}$. MilneEdwards 1853 dalam yamindago et al. 2013; WORMS, 2019). Kepiting tersebut teridentifikasi sebagai kepiting Metopograpsus sp yang berjenis kelamin betina

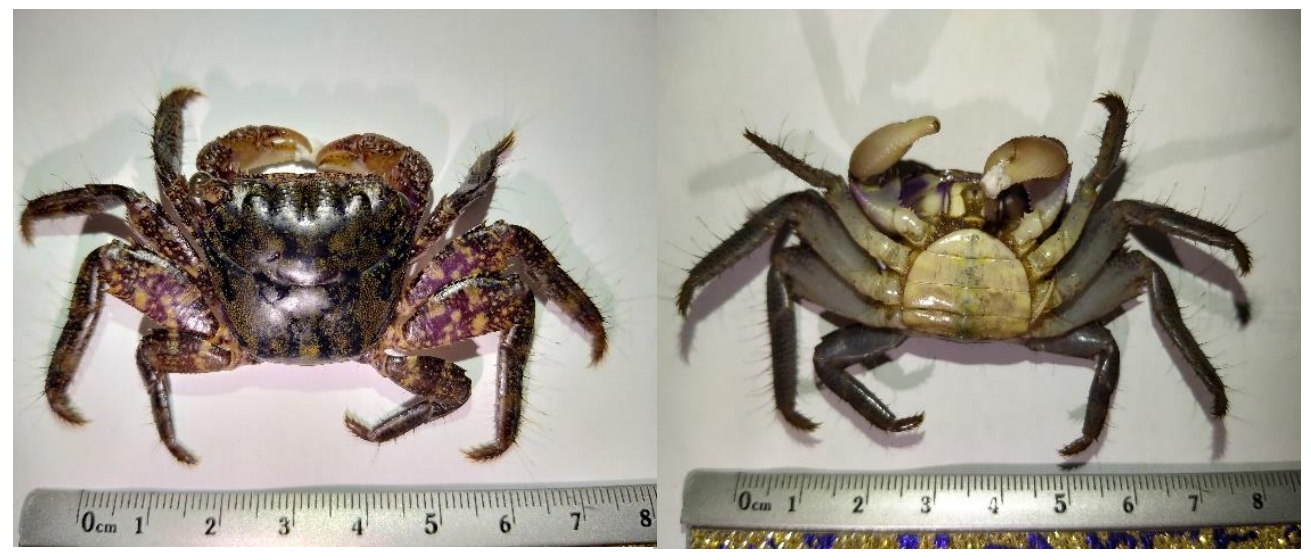

Gambar 2. Kepiting Metopograpsus sp

\section{Konsentrasi dan Kandungan Pigmen Total Karotenoid}

Konsentrasi dan Kandungan Pigmen Karotenoid pada kepiting Metopograpsus sp dapat dilihat pada Tabel 1.

Tabel 1. Nilai konsentrasi dan kandungan pigmen karotenoid pada kepiting Metopograpsus $\mathrm{sp}$

\begin{tabular}{|l|c|c|}
\hline \multicolumn{1}{|c|}{ Organ tubuh } & $\begin{array}{c}\text { Konsentrasi Pigmen (C) / } \\
\boldsymbol{\mu g} \mathbf{g r} \text { berat residu kering }\end{array}$ & $\begin{array}{c}\text { Kandungan Pigmen (Q) / } \\
(\boldsymbol{\mu g})\end{array}$ \\
\hline Karapas & 16,16 & 18,47 \\
\hline Lapisan Epidermis & 35,07 & 21,71 \\
\hline Hepatopankreas & 9,71 & 6,47 \\
\hline Darah(haemocyanin) & 13,23 & 8,19 \\
\hline Gonad & 11,07 & 6,85 \\
\hline
\end{tabular}

Hasil konsentrasi pigmen total pada masing-masing organ kepiting Metopograpsus sp diperoleh nilai tertinggi berada pada organ lapisan epidermis dengan konsentrasi 35,07 $\mathrm{\mu g} / \mathrm{gr}$ berat residu kering, diikuti organ karapas, darah, gonad dan hepatopankreas. Hal ini ditunjang juga oleh Bliss and Mantel (1985), tingginya nilai konsentrasi pada organ lapisan epidermis dikarenakan metabolit sekunder pada kepiting berupa pigmen karotenoid banyak tertumpuk pada lapisan epidermis sebelum terakumulasi ke karapas. Rendahnya konsentrasi pada organ Hepatopankreas diasumsikan bahwa alur metabolit sekunder pada kepiting berupa pigmen karotenoid tidak tertumpuk pada hepatopankreas. 
Nilai kandungan pigmen total dari masingmasing organ pada kepiting Metopograpsus sp menunjukkan nilai tertinggi pada organ lapisan epidermis $(21,71 \mu \mathrm{g} / \mathrm{gr})$, diikuti organ karapas $(18,47$ $\mu \mathrm{g} / \mathrm{gr})$, darah/haemocyanin $(8,19 \mu \mathrm{g} / \mathrm{gr})$, gonad $(6,85 \mu \mathrm{g} / \mathrm{gr})$ dan hepatopancreas $(6,47 \mu \mathrm{g} / \mathrm{gr})$. Rendahnya kandungan pigmen karotenoid pada darah diasumsikan dari fungsi darah (haemocyanin) yang hanya sebagai pengangkut makanan, oksigen dan $\mathrm{CO}_{2}$.
Menurut Suwignyo dkk (2005), pada dasarnya fungsi darah mengangkut material makanan dari satu bagian tubuh ke bagian tubuh lainnya, mengangkut oksigen dari insang menuju jaringanjaringan tubuh, mengangkut $\mathrm{CO}_{2}$ menuju ke insang dan mengangkut urea menuju alat ekskresi.

Jenis Pigmen Karotenoid: Jenis pigmen karotenoid hasil pemisahan KLT terdapat 5 fraksi yang tertera pada Tabel 2 .

Tabel 2. Jenis pigmen karotenoid hasil pemisahan KLT dan serapan spektrofotometer

\begin{tabular}{|c|c|c|c|l|}
\hline FRAKSI & RF & WARNA & $\begin{array}{c}\text { PANJANG } \\
\text { GELOMBANG }(\mathrm{nm})\end{array}$ & JENIS PIGMEN \\
\hline 1 & 1,0 & Kuning & $424,451,476$ & $\beta$-karoten \\
\hline 2 & 0,97 & Merah & - & Tidak teridentifikasi \\
\hline 3 & 0,66 & Merah & 468 & Astaxanthin \\
\hline 4 & 0,50 & Merah & 474 & Astacene \\
\hline 5 & 0,43 & Kuning & - & Tidak teridentifikasi \\
\hline
\end{tabular}

Fraksi 1 memiliki tiga panjang gelombang serapan spektrofotometer dengan Panjang gelombang 424,451,476 nm (Gambar 3). Menurut Britton dkk (1995), bahwa hasil pemisahan KLT dan serapan maksimum spektrofotometer di atas teridentifikasi sebagai pigmen $\beta$-karoten. Balaira $d k k$ (2017), juga menemukan pigmen $\beta$ karoten pada alga Dunailiella salina. Pigmen $\beta$-karoten juga ditemukan pada kepiting Grapsus sp. betina (Abdullah $d k k$, 2018), dan pada cangkang Littoraria pallescens juga ditemukan pigmen $\beta$ karoten (Sumampouw dkk, 2018)

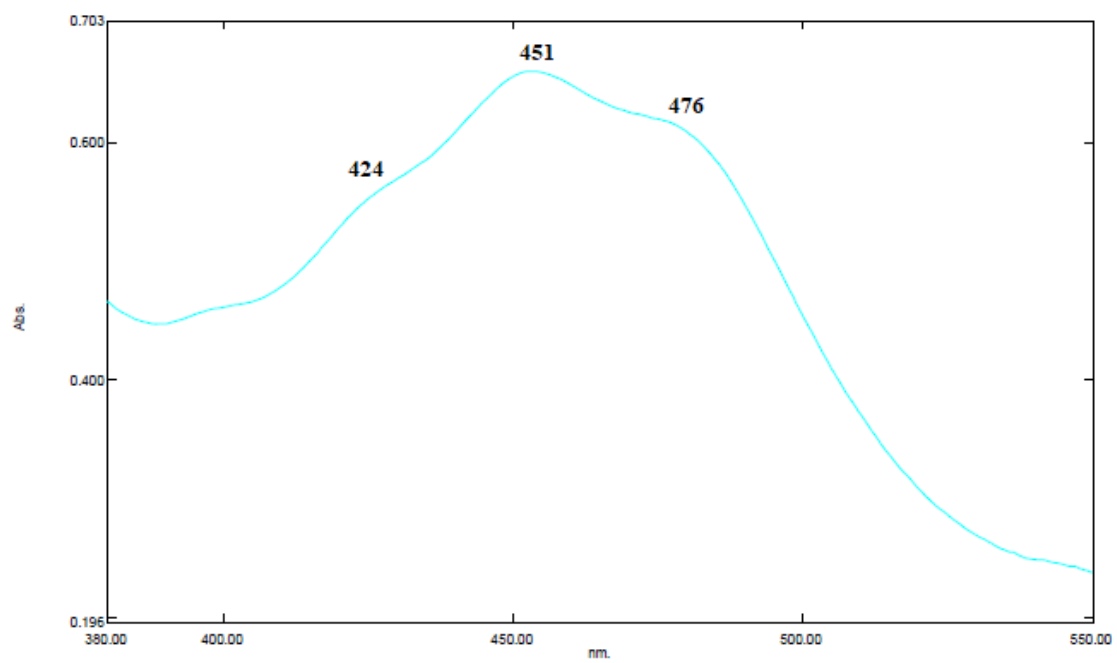

Gambar 3. Spektogram pigmen $\beta$-karoten

Pada fraksi ke-2 tidak terbentuk puncak serapan maksimum spektrofotometer, sehingga jenis pigmen pada fraksi tersebut tidak dapat teridentifikasi. Hal yang sama terjadi pada fraksi ke-5. Menurut Stahl (1985), bahwa tidak teridentifikasinya suatu fraksi karena kurangnya kepolaran dari larutan pengembang sehingga 
mengakibatkan senyawa pigmen tidak mampu bermigrasi terlepas dari senyawa lain yang masih tercampur.

Pada fraksi 3 membentuk satu puncak serapan maksimum spektrofotometer dengan panjang gelombang $468 \mathrm{~nm}$ (Gambar 4). Menurut Britton dkk (1995), bahwa hasil pemisahan KLT dan serapan maksimum spektrofotometer di atas teridentifikasi jenis pigmennya Astaxanthin. Pigmen astaxanthin juga ditemui pada kepiting Uca vocans jantan (Mantiri $d k k, 2002)$, kepiting bakau Scylla serrata (Paransa dan Abdullah, 2007), dan juga kepiting Grapsus sp Betina (Abdullah $d k k, 2018)$

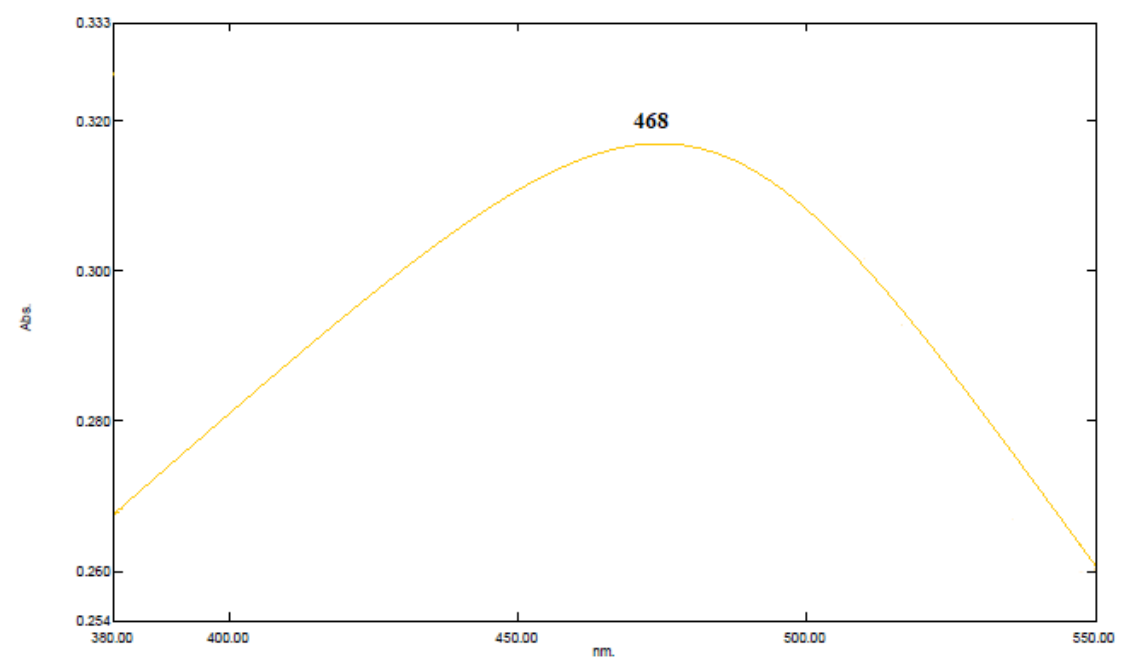

Gambar 4. Spektogram pigmen astaxanthin

Pada fraksi 4 membentuk puncak serapan maksimum spektrofotometer yang memiliki satu puncak $474 \mathrm{~nm}$ (Gambar 5). Menurut Britton dkk (1995), bahwa hasil pemisahan KLT dan serapan maksimum spektrofotometer teridentifikasi sebagai Astacene. Pigmen astacene juga ditemui pada kepiting Grapsus sp. betina dari hasil penelitian Abdullah dkk, (2018), kepiting Grapsus albolineatus betina (Makalalag $d k k, 2017)$. Pigmen astacene juga ditemukan pada mikroalga Nannochloropsis sp dengan larutan pengembang Petrolium Eter dan Methanol dengan perbandingan 95:5 (Bawias dkk, 2018)

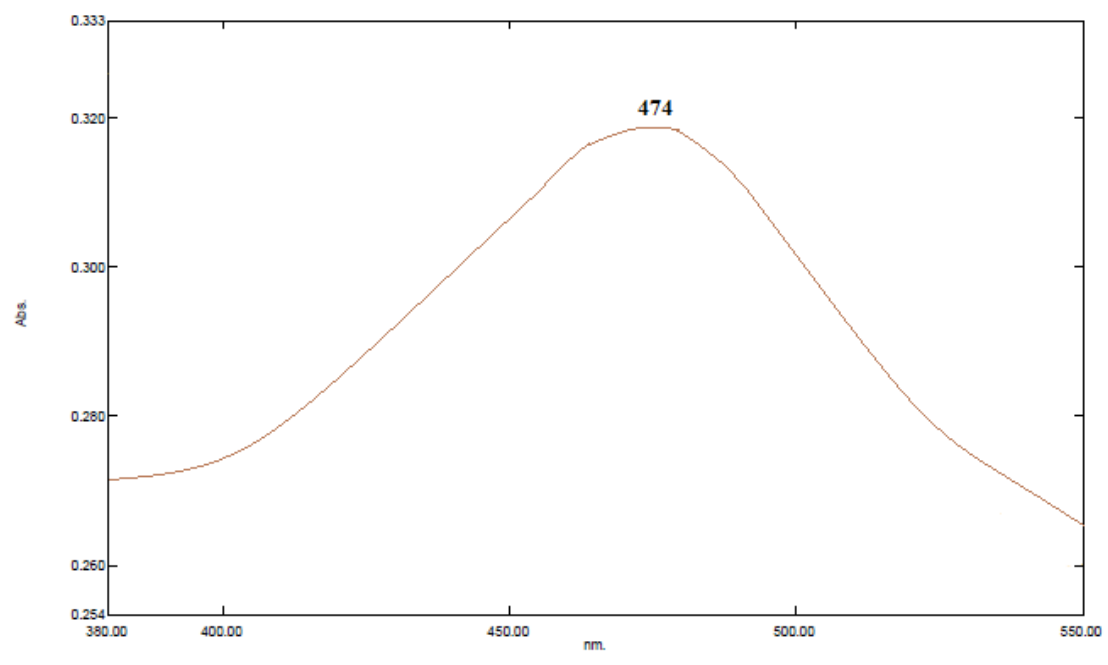

Gambar 5. Spektogram pigmen astacene 


\section{Kesimpulan}

Berdasarkan hasil penelitian di atas maka dapat disimpulkan bahwa :

1. Jenis pigmen yang teridentifikasi pada kepiting Metopograpsus sp yaitu : $\beta$-karoten, Astaxanthin, Astacene

2. Konsentrasi Pigmen (C) tertinggi terdapat pada ekstrak lapisan epidermis dengan konsentrasi (35,07 $\mu \mathrm{g} / \mathrm{gr}$ ) berat residu kering, diikuti organ karapas $(16,16 \mu \mathrm{g} / \mathrm{gr})$, darah $(13,23 \mu \mathrm{g} / \mathrm{gr})$, gonad $(11,07$ $\mu \mathrm{g} / \mathrm{gr})$ dan hepatopankreas $(9,71$ $\mu \mathrm{g} / \mathrm{gr}$ ) dan kandungan Pigmen (Q) tertinggi pada organ lapisan epidermis $(21,71 \mu \mathrm{g} / \mathrm{gr})$, diikuti organ karapas $(18,47 \mu \mathrm{g} / \mathrm{gr})$, darah/haemocyanin $(8,19 \mu \mathrm{g} / \mathrm{gr})$, gonad $(6,85 \mu \mathrm{g} / \mathrm{gr}) \quad$ dan hepatopancreas $(6,47 \mu \mathrm{g} / \mathrm{gr})$.

\section{DAFTAR PUSTAKA}

Abdullah, M.R, Paransa, D.S.J, dan Mantiri, D.M.H. 2018. Distribusi Pigmen Karotenoid Pada Kepiting Grapsus sp. Dengan Menggunakan Metode Kromatografi Lapis Tipis. Jurnal Pesisir dan Laut Tropis. Vol. 2 No. 1 Tahun 2018. Hal 23-24

Balaira, G.Y., Kemer, K, dan Mantiri, D.M.H. 2017. Pemisahan Pigmen Pada Mikroalga Dunaliella salina Yang Telah Diberi Senyawa Timbal Asetat. Jurnal Pesisir dan Laut Tropis. Vol. 1 No. 1 Tahun 2017. $\mathrm{Hal} 47$.

Bawias, M., Kemer, K., Mantiri, D.M.H. 2018, Isolasi pigmen karotenoid pada mikroalga Nannochloropsis sp. Dengan menggunakan beda pelarut. Jurnal pesisir dan laut tropis. Vol 2 No 1. Tahun 2018. Hal 1-8.

Bliss, D. E. dan L. H. Mantel. 1985. Integument, Pigments And Hormonalprocess In The Biology Of Crustacea. Vol 9. Academic Press inc. Orlando-Frorida. Hal 44-128.

Britton, G., S.L. Jansen and H. Pfander. 1995. Caratenoids. Volume 1B.
Spectroscopy. Basel, Switzerland. Hal. 347

Makalalag, S., Paransa J.S.D., Mantiri, D.M.H. $2017 . \quad$ Penentuan Kandungan Pigmen Karetenoid pada Kepiting Grapsus albolineatus (Lamarck) Betina dari Perairan pesisir Pantai Tanawangko. Jurnal pesisir dan Laut Tropis, 3 (1) : Hal 1 $-9$

Mantiri, D.H.M. 1997. Nature, localization et metabolisme des carotenoides et des complexes carotenoproteiques us Cours de levolution embryonnaire et laveire du Hummard European Humarus gammarus (Linne 1758). These. Universite De Droit, D'Economie et des Sciences D'Aix Maerselle. Faculte des Sciences et Techniques de Saint Gerome. 115. Mantiri, D. H. M., D.J Paransa dan J.F. Koagow. 2002. Telaah Awal Kandungan Pigmen Karotenoid Pada Kepiting Biola Uca vocans Jantan. Jurnal Perikanan dan IImu Kelautan. Vol I. No. I. FPIK. UNSRAT. Hal 43-47

Paransa, D dan Abdullah. Z. 2007. Isolasi Karotenoid Pada Ekstrak Kepiting Bakau Scylla serrata (Forskal 1755). Jurnal warta - WIPTEK No 29/Th.2007/Maret. ISSN : 08540067

Poore, C.B Gary. 2004. Marine Decapode Crustacea Of Southern Australia. A Guide To Indentification. CSIRO Publishing. Australia. Hal 574.

Poupin J. and M. Juncker. 2010. A Guide To The Decapod Crustaceans Of The South Pacific ISBN: 978-98200-0423-8 hal 123-260

Pratiwi R. \& Rahmat. 2015. Sebaran Kepiting Mangrove (Crustacea: Decapoda) yang terdaftar di Koleksi Rujukan Pusat Penelitian Oseanografi-Lipi 1960-1970. Jurnal Ilmu-ilmu Hayati. 14(2): Hal 195202.

Prianto, E. 2007. Peran Kepiting Sebagai Spesies Kunci (Keystone Spesies) Pada Ekosistem Mangrove. Prosiding Forum Perairan Umum Indonesia IV. Balai Riset Perikanan Perairan Umum. Banyuasin. 
Rohman A. 2009. Kromatografi untuk analisis obat. Edisi Pertama-Graha IImu. Hal : 1-232

Sari, D.P dan Abdiani, I.M. 2015. Pemanfaatan Kulit Udang Dan Cangkang Kepiting Sebagai Bahan Baku Kitosan. Jurnal Harpodon Borneo, 8(2). Hal 142-147.

Stahl, E. 1985. Analisis Obat Secara Kromatografi dan Mikroskopi penerbit ITB. Bandung. Hal 3-19

Sumampouw, S. M., Mantiri, D. H. M., Boneka, F. B. 2018. Klasifikasi warna cangkang dan pigmen karotenoid pada cangkang Littoraria pallescens (Philippi, 1846) dari wilayah ekosistem mangrove Desa Mokupa Kecamatan Tomboriri dan Desa Basaan Kecamatan Ratatotok. Jurnal IImiah Platax. Vol. 6:(2). Hal 98-105
Suwignyo, S,. B. Widigndo, Y. Wardianto dan M. Krisanti 2005 Avertebrata Air Jilid 1. Penebar Swadaya. Jakarta. Hal 1-188.

World Register Of Marine Spesies.2019. Diakses pada tanggal 7 agustus 2019 (20:00), dari http://www.marinespecies.org/aphia. php? $p=$ taxdetails\&id $=207537$

Yamindago, Ade \& Senanan, Wansuk \& Tangkrock-olan, Nongnud. (2013). Verification on Morphological Identification of Grapsid Crabs Genus Metopograpsus H. Milne Edwards, 1853 from Chon Buri Province Using Partial Sequences of Mitochondrial 16S rRNA, 12S rRNA and Cytochrome c Oxidase Subunit I (COI) Genes. Burapha Science Journal. 18. Hal 181-19 